\title{
On the meteorological interpretation of Pleistocene climate fluctuations
}

\author{
Hermann Flohn \\ Meteorologisches Institut, Universität Bonn, 5300 Bonn, Germany \\ Correspondence: Christine Thiel (christine.thiel@bgr.de) \\ Relevant dates: $\quad$ Published: 17 December 2021
}

How to cite: $\quad$ Flohn, H.: On the meteorological interpretation of Pleistocene climate fluctuations, DEUQUA Spec. Pub., 3, 61-66, https://doi.org/10.5194/deuquasp-3-61-2021, 2021.

Special issue statement. This article is part of a special issue published on the occasion of the 70th anniversary of $E \& G$ Quaternary Science Journal (EGQSJ). The special issue celebrates the journal's notable contribution to Quaternary research by revisiting selected milestone articles published in the long history of EGQSJ. The German Quaternary Association (DEUQUA) presents translations of the originals and critical appraisals of their impact in tandem anniversary issues of DEUQUASP and EGQSJ, respectively.

Original article: https://doi.org/10.3285/eg.14.1.17

Tribute: https://doi.org/10.5194/egqsj-70-2252021

Translators: Clare Bamford, Christine Thiel and Henrik Rother

\section{Introduction}

In geology, the proven principle of uniformitarianism also plays an essential role in the discussion on climate fluctuations in past geological times. If one wants to infer meteorological-climatological processes from the geographical distribution of ice sheets and mountain glaciations, one arrives at the idea that the climatic anomalies associated with the past formation and maximum extent during the most recent ice age show a remarkable parallel to those weather processes characterizing the severe winters in Europe (Flohn, 1952). In the meteorological-climatological interpretation of the geological findings, however, we must proceed with cau- tion so as not to confuse various large-scale weather types, which often have quite different effects on the regional climate. If we adopt the hemispheric classification of H. C. Willett in its revised form (Willett and Sanders, 1959), then this phase is not so much a pure "low-index circulation" but a "high-index circulation in the low latitudes". Here, at midlatitudes $\left(40-60^{\circ}\right)$, there is a meridional splitting of the tropospheric westerly drift into obstructive highs and quasistationary lows, which are most pronounced at $300 \mathrm{mb}$ pressure (corresponding to about $9 \mathrm{~km}$ altitude). At the same time, however, the high-tropospheric zonal westerly drift is also intensified and concentrated over subtropical latitudes, primarily due to thermal effects of continental inland ice masses in North America and Europe. A climatological interpretation of the conditions at the southern edge of the two inland ice sheets inevitably leads to the idea of a very intensive, west-east running frontal zone at about $40^{\circ}$ latitude in central and eastern North America and at about $45^{\circ}$ latitude in the European Mediterranean and Black Sea area (see also Willett, 1950). This means frequent and intense precipitation over these areas, heavy cloud cover and cool temperatures throughout the year, and an enhanced positional stability of the "polar front" (and the jet streams coupled with it) at relatively short distance from the subtropical jet stream.

Such an uniformitarian interpretation - the physicalmeteorological justification for which will not be discussed here - could be taken further both regionally and temporally. But this approach also has its limits: there are unequivocal geological findings whose meteorological interpretation 
finds no support from present observations and experiences. The closest example is that of "acryogenic" polar climates with an ice-free polar region (Brooks, 1949), for which there is no current analogy. Conclusive evidence for such an icefree polar climate exists in the interglacial period in the Arctic Ocean region and appears to apply to the postglacial warm period as well. In contrast, the Antarctic continent was probably permanently glaciated during all of the Pleistocene interglacial periods (see Sect. 3). Now, if on the entire Arctic Ocean, the near-sea air temperature during the polar summer would be about $+5^{\circ} \mathrm{C}$ instead of $0^{\circ}$, in winter $-1^{\circ}$ instead of $-30^{\circ}$, and if the albedo drops from today's 30\%-50\% in summer, and $50 \%-80 \%$ in winter to $2 \%-5 \%$, then this would result in much lower meridional temperature gradients and thus a substantial weakening of the westward drift by 20\%-30\% (Flohn, 1959b). The effects of this certainly extend into the subtropics, and even the marginal tropics. Questions of this kind, which can no longer be answered by means of modern analogies, no longer need to be left to the wild imagination of popular authors: they are accessible by rational, physical-mathematical considerations and model calculations.

The analogies between the anomalies associated with large-scale atmospheric circulation changes that in turn have been responsible for climate fluctuations over modern, historical, and the Pleistocene periods have been pointed out in recent years, above all by Lamb and Johnson (1959), Lamb (1963). In the following, some (by no means new) ideas on the meteorological-climatological interpretation of the Pleistocene climate fluctuations will be discussed. Since it is not possible for the author to review the extensive geological literature and to cite it in detail (cf. Woldstedt, 1961), he presents the relevant lines of thought only in brief for discussion. Of course, the task of the meteorologist here can only consist of an interpretation of geological findings. The application of modern physical techniques - in particular, dating and temperature determination by means of radioactive or stable isotopes - today provides us with quantitative data, the interpretation of which, however, must be approached with all methodological criticism and care.

\section{Are pluvials and ice ages synchronous?}

Over recent decades, it has been common to equate pluvial periods in the subtropical and tropical dry regions of the northern hemisphere to the glacial periods. This leads many authors to believe that during the ice ages the earth's dry belts were constricted from both hemispheres. In reality, however, clear age control of pluvial deposits is not yet available for many areas, so that the view of simultaneity is only too often based on assumed analogies.

In this context, it has often been hypothesised (also by Flohn, 1952) that during the ice ages with their increased meridional circulation - which also characterises the above- mentioned type of "high index in low latitudes" - the subtropical high-pressure belt was weakened, and the tropicalequatorial precipitation zone was more widespread. Such a correlation is based, for example, for the Indian subcontinent from the occurrence of intense tropical (cyclonic) disturbances in connection with high-altitude high-pressure troughs within the westward drift, which extend far poleward on their frontal side. In contrast, Willett (1950) took the view that in times of increased meridional circulation (low index) the subtropical high-pressure belt would have shifted equatorwards as a whole.

In the meantime, this question has received new attention. It seems to be certain (cf. Butzer, 1958) that pluvial conditions prevailed in large areas of the Middle East and North Africa in the postglacial warm period, i.e., about 3000-5000 BC. It has been difficult for meteorologists to harmonise this with the previous understanding of atmospheric circulation, since in the case of an intensified, polewardshifted subtropical high - as must be assumed to explain the postglacial warm period - the correlation of an upper level trough - tropical disturbance would not have occurred more frequently, but instead less frequently than today. In the meantime, an explanation for this discrepancy can be found in the following, still little-known meteorological experience:

In North Africa today, it is not uncommon for tropical disturbances to move as far as Egypt in late summer (several individual cases have been described for the months of August to October), which can reach as far as the Egyptian Mediterranean coast and bringing precipitation as far as $25-27^{\circ} \mathrm{N}$ (Koch, 1950; Abd el-Hady, 1961). This also explains the peculiar climatic notes from Alexandria in the Ptolemaic period (Brooks, 1949, p. 333), reporting (similar to todays situation in the area of Quetta/Peshawar) a second summer rain season with thunderstorms in addition to the winter rain season that dominates today. According to these findings, equatorial disturbances can also penetrate to subtropical latitudes (28$32^{\circ} \mathrm{N}$ ) in periods with pronounced zonal circulation at high latitudes, i.e., with a subtropical high that is shifted poleward. This would make the findings (Butzer et al., 1958) of a humid period in North Africa and the Middle East during the postglacial warm period meteorologically interpretable in an uniformitarian sense; a few events of this nature per year would be sufficient to increase the mean annual rainfall by perhaps $100 \mathrm{~mm}$, with profound consequences for vegetation, fauna and hydrology.

In light of this finding, reservations (Balout, 1952; Schwarzbach, 1953) against the simultaneity of the pluvial and glacial come in a new form (cf. also Büdel, 1963). In the future, a clear distinction will have to be made between a "polar" pluvial, which is primarily due to the equatorward reaching winter rainfall associated with the "polar front" more correctly: with the weather-effective mechanisms of the extratropical westward drift - and which occurs simul- 
taneously with the ice ages, and a tropical pluvial ${ }^{1}$. The latter pluvial conversely occurs during "interglacial" periods with an intensified, northward shifted subtropical high delivering predominantly tropical summer rainfalls. Both can occur in the same areas and during the same periods, as is currently the case for extreme weather conditions. Accordingly, it is undoubtedly no longer permissible to correlate pluvialtemporal deposits in today's dry zone with the ice ages, at least not without further investigation. Only with precise dating based on modern methods can erroneous conclusions be avoided here; perhaps in the future it will even be possible to distinguish between winter and summer rains based on exact temperature determinations for the respective soil formations. On the other hand, it is necessary to examine intensity and extent of (current) precipitation for different parts of the tropical zone from a meteorological point of view and establish their connection to the circulation types of the westward drift. Only such an (uniformitarian) investigation can clarify the connections between the alternating pluvials of the tropical and subtropical zones and the extratropical glacials.

\section{On the question of the eustatic subsidence of the world ocean in the interglacial periods}

The eustatic sea-level fluctuations between the ice ages on the one hand, and the interglacial periods (including postglacial) on the other, are generally interpreted as consequence of the turnover of water into the solid or liquid form between the two large reservoirs - the world ocean and continental ice sheets. In this sense, the eustatic fluctuations (Fairbridge, 1961a, b; Graul, 1960) form globally integrated measures of continental glaciation and allow some quantitative estimates. However, we must not equate the ice mass stored on the mainland with the amount of water withdrawn from the sea without further consideration. Because it presupposes first of all that the storage of water vapour in the air (today corresponding to $2.4 \mathrm{~cm}$ of precipitation water) is negligible and that the global annual amount of precipitation and evaporation would be subject to only subordinate fluctuations. As of now, this is known only inaccurately due to the major difficulties of taking measurements on the vast ocean surface: according to the majority of "western" authors the value is 81$86 \mathrm{~cm} / \mathrm{a}$, but according to Budyko it is about $93 \mathrm{~cm} / \mathrm{a}$. This means that each water vapour molecule remains in the atmosphere on average for only $11-13 \mathrm{~d}$, whereas it remains in the ocean for about 4000 years. An estimate of the residence time in the Antarctic ice sheet is far more uncertain: a large part

\footnotetext{
${ }^{1}$ The author proposes these two terms because the terms "Etesian winds" and "monsoons" used by Balout and his meteorological advisor Dudief - the best expert on the Sahara climate - are used somewhat ambiguously in an extended sense: the Etesians are dry $\mathrm{N}$ winds in the Mediterranean region in summer, and the "monsoon", which permeates the entire African continent, blows from the SW all year round in its core area on both sides of the equator.
}

of the precipitation is removed again relatively quickly by snow sweeping and glacier movement, while in the interior the very cold (approx. $-28^{\circ} \mathrm{C}$ ) ice masses only move very little; an average value of at least 20000 years therefore says little. Furthermore, we have to take into account the changes in the horizontal extent of the world's oceans, whereby the drying up of large shelf seas and the flooding of large lowlands urgently require an exact quantitative estimate. Another factor that should not be completely neglected is the change in density of the seawater with temperature: with an average thermal expansion coefficient of 0.00014 and an average ocean depth of $3800 \mathrm{~m}$, a temperature decrease of $5^{\circ} \mathrm{C}$ yields a sea level decrease of $2.66 \mathrm{~m}$.

One of the most striking phenomena is the apparently continuous (Zeuner, 1950; Fairbridge, 1961a) eustatic fall of the interglacial sea levels by at least $80 \mathrm{~m}$ since the Sicilian, i.e., in a period which, according to the older time scale, amounts to about 650000 years. This corresponds to a mean annual change in level of $-0.12 \mathrm{~mm} / \mathrm{a}$. The interpretation of this process is usually attributed to a slow subsidence of the sea floor, for example in the Pacific (tectono-eustasy). There is evidence of such subsidence - in the shallow surfaces of the submarine guyots - but its amount and temporal position are still largely hypothetical.

Another, so far apparently neglected, model assumes the formation of the Antarctic ice. We can imagine that, according to palaeomagnetic data, the Antarctic continent drifted close to the South Pole in the Pliocene and then - perhaps at the turn of the Plio/Pleistocene - slowly formed a flat ice cap (Fairbridge, 1961b), which initially remained for a long time under the conditions of a "temperate" glacier (rapid movement, melting of the surface in summer with enormous radiation, an albedo of $0 \%$ ) with approximately stationary ice formation. The importance of this difference between temperate and cold glaciers for the ice balance of inland ice areas was particularly emphasised by Hoinkes (1961). This was accompanied by a gradual decrease in sea temperature, as evidenced by deep-sea drilling cores (Emiliani, 1961). But it was not until the course of the oldest Pleistocene that general cooling - the cause of which will not be speculated here led to a drop in summer temperatures below $0^{\circ}$ and to the conditions of a "cold" glacier (little movement, temperatures constantly $<0^{\circ}$, albedo $85 \%-95 \%$ ). Since the sum of precipitation was now greater than the sum of all losses, the ice mass balance now became positive. The Antarctic ice sheet - which during the warm glacier stage was perhaps only $300 \mathrm{~m}$ thick on average (corresponding to an ice mass of about $4106 \mathrm{~km}^{3}$ and a sinking of the world's oceans by almost $10 \mathrm{~m}$ ) - now steadily grew albeit under some fluctuations. If we neglect these oscillations and assume a mean value for the build-up of Antarctic ice for the entire period since the Sicilian (Günz/Mindel interglacial or pre-Günz?), then the mean sea-level change of $-0.12 \mathrm{~mm} / \mathrm{a}$ corresponds to an increase in Antarctic ice of $3.8 \mathrm{~mm} / \mathrm{a}$, comparable to today's value of at least $+2 \mathrm{~cm} / \mathrm{a}$ (Hoinkes, 1961). In general 
magnitude these numbers agree satisfactorily, especially if one considers that the structure of the Antarctic ice was subject to considerable temporal fluctuations. It should certainly not be assumed that these fluctuations were synchronous with the change between ice age and interglacial in the Northern Hemisphere. Since R. F. Scott and Meinardus, many authors - such as Büdel (1960) - have pointed out the likelihood of an opposite trend - growth in the relatively warm interglacials, stagnation or decline in the ice ages. Furthermore, at a point in time that cannot yet be determined, the Antarctic ice sheet was at least $300 \mathrm{~m}$ thicker than today (Hoinkes, 1961), which corresponds to a mass loss of about $15 \%$. If we also take today's increase of $2 \mathrm{~cm} / \mathrm{a}$ as a representative value for the opposing trend - probably an overestimate! - then the ice maximum would have occurred at least 15000 a ago. Perhaps we may move forward with the working hypothesis that the ice maximum is unlikely to have taken place later than the $\mathrm{R} / \mathrm{W}$ interglacial (Eemian transgression), at least not in the postglacial period.

If we take today's estimated best value of $28106 \mathrm{~km}^{3}$ for the mean mass of the Antarctic ice sheet (Hoinkes, 1961), then the water volume of $25.2 \times 10^{15} \mathrm{~m}^{3}$ (here including the shallow Pliocene ice sheet assumed above) corresponds to a sea level rise of about $70 \mathrm{~m}$. If we assume an expansion of the sea surface by flooding the vast lowland landscapes by only $4 \%\left(=14.5 \times 10^{6} \mathrm{~km}^{2}\right)$, the potential sea level rise is reduced to $66 \mathrm{~m}^{2}$. This is not quite enough to explain the observed eustatic subsidence since the Sicilian. But there is no doubt that the Antarctic mainland (as well as Greenland) has been pushed considerably below sea level by the ice load. The magnitude and sign of the isostatic level fluctuations caused by this can only be estimated hypothetically, but it likely explains the remaining difference.

Compared to all large-scale tectonic hypotheses, this glacial-eustatic hypothesis for the Pleistocene sea level fluctuations (including the interglacial subsidence) has some advantages, especially that of consistency. It presupposes that physical-climatic conditions prevailed in the Antarctic region from the beginning of the Pleistocene which, with only gradual fluctuations, were roughly similar to today's, but differed in principle from those of the entire Tertiary. In this context, it would be important to clarify how long the Greenland ice sheet has existed and whether - despite its much smaller extent - it has survived one or more warm periods.

Our hypothesis leads to some important conclusions about the large-scale climate sequence of the Pleistocene. If the Antarctic ice sheet already existed in the oldest Pleistocene (i.e., before the "Günz" glaciation), maybe only as a "temperate glacier", then this would have been sufficient for a

\footnotetext{
${ }^{2}$ To these estimated amounts one must add - as Paul Woldstedt rightly pointed out to the author - the amount of water fixed in the inland ice of Greenland, which according to today's best estimate amounts to about $2.5 \times 10^{15} \mathrm{~m}^{3}$; then we arrive at a sea level in the Sicilian of about +76 and $72 \mathrm{~m}$, respectively.
}

considerable increase in the southern hemispheric westward drift (Flohn, 1959b) by perhaps 50\% compared to a hypothetical "acryogenic" state. While in the ice-free Tertiary and Mesozoic the tropical-subtropical wind and climate belts due to the considerably lower meridional temperature gradient - evidently extended further poleward than today and the subpolar low-pressure zone was restricted to the polar caps, thus narrowing and shifting of these climate belts towards the equator. If the Antarctic inland ice formed earlier than the ice sheets of the northern hemisphere (because of the location of the Antarctic mainland closer to the poles), then a very characteristic phenomenon appeared for the first time: an asymmetry of the tropical circulation belts in relation to the equator, with the much more intensive westward drift of the southern hemisphere pushing the meteorological equator towards the northern hemisphere all year round. Such an equatorial asymmetry also exists today (e.g., Flohn, 1959a), albeit to a weaker extent; today the meteorological equator lies on an annual mean at $5-7^{\circ} \mathrm{N}$, and over the sea ice of the Arctic the troposphere is about $5^{\circ} \mathrm{C}$ warmer in winter and about $10^{\circ} \mathrm{C}$ warmer in summer than over Antarctica. The equatorial asymmetry was reduced after extensive glaciation of Greenland and the Barents Sea shelf (Büdel, 1963) had formed for the first time - possibly with a considerable delay compared to Antarctica, but certainly earlier than the Laurentian or Scandinavian ice. But this increased the northern hemispheric westward drift in a similar way to that of the southern hemisphere, at least during the cold periods. This asymmetry of the meteorological equator probably reached its peak during the warm periods of the oldest and older Pleistocene, and a minimum during the last cold periods ("Riß", "Würm"). These processes, which are to be expected for meteorological reasons, have very far-reaching consequences for the climatic history of the non-glacial tropical-subtropical zones, which, can only be assessed with accuracy after reliable worldwide age dating become available. These are shifts and expansions of the equatorial rainfall zones and the subtropical dry zones with their seasonally alternating transition belts of the tropical summer rainfall zone and the subtropical winter rainfall zone.

\section{Eustatic sea level rise in the late and postglacial periods and heat balance budget}

The melting of the large inland ice masses of northern Europe and North America during late and postglacial times initially required a complete rearrangement of the atmospheric circulation, similar to that which brings about the change from a severe winter to a period of widespread thaw. This rearrangement also led to a drastic change in the heat balance, although the accumulation of snow and ice and its associated high albedo and long-wave outward radiation, accompanied by the strong production of cold air flowing off catabatically, initially continued to exist unchanged. Since the maximum 
possible change in solar irradiation - based on the astronomical theory of climate change - proceed only slowly and amount to only a few percent, the momentous upheaval in the large-scale weather situations must be largely advective in nature, i.e., related to meteorological-climatological processes in the permanently unglaciated parts of the Earth's surface. The continental ice sheets (including Antarctica) occupied a maximum of $45 \times 10^{6} \mathrm{~km}^{2}=8.8 \%$ of the Earth's surface - compared to about $15 \times 10^{6} \mathrm{~km}^{2}$ or about $3 \%$ today - , the sea-ice covered oceans perhaps another $30 \times 16^{6} \mathrm{~km}^{2}$. Thus, a total of about $15 \%$ of the Earth's surface was directly under a "cryogenic" climate influence, yet still $85 \%$ - importantly the entire tropical and subtropical zone! - remained under the normal conditions of an "acryogenic" heat balance.

What demands did the postglacial melting of the northern hemispheric inland ice masses poses for the global heat balance? According to Fairbridge (1961a), a strong sealevel rise occurred between the Early Dryas (Valders stage, ca. $8400 \mathrm{BC}$ ) and the beginning of the postglacial warmth optimum (Early Peron transgression, ca. $3800 \mathrm{BC}$ ): here a rise of a full $42 \mathrm{~m}$ was observed $4600 \mathrm{a}$ ago, i.e., by around $9 \mathrm{~mm} / \mathrm{a}$. This rise was particularly concentrated in the period from the Valders stage to the beginning of the Cochrane advance (corresponding to the Yoldia stage of the Baltic Sea area, ca. $6600 \mathrm{BC}$ ). During this period, according to the concordant data of Graul (1960) and Fairbridge (1961a), we have to expect an increase of about $27 \mathrm{~m}$ in about 1800 years, i.e., about $15 \mathrm{~mm} / \mathrm{a}$. For this relatively short period of time, we can tentatively assume a stationary ice balance for the Antarctic since the ice retreat there prohibits any assumption of a positive ice balance (as is the case today).

If we neglect the smaller ice centres, this increase of $15 \mathrm{~mm} / \mathrm{a}$ corresponds to a melting loss of about $24 \mathrm{~cm} / \mathrm{a}$ for the main glaciation centres of North America and Northern Europe - whose area had decreased by about $15 \%$ compared to the peak (cf. Graul, 1960). This value does not seem unreasonable if we compare it with the recent shrinkage of the isolated Eastern Alpine glaciers by about $60 \mathrm{~cm} / \mathrm{a}$. An annual melting of $21.6 \mathrm{~cm}$ of water equivalent requires about $1730 \mathrm{gcal} / \mathrm{cm}^{2}$; this in turn would amount to an annual average of just under $1 \%$ of the (global) extraterrestrial irradiation onto a horizontal surface, but somewhat more during the short summer period (where the melting is concentrated). It would be an interesting task, using our current knowledge on the heat and mass balance of glaciers - which behave very differently across individual climate zones! - to estimate these values for the inland ice masses of the postglacial period. As is well known, the high albedo of the firn ice plays a decisive role. Under these circumstances, the annual average effective irradiation is only slightly higher than the effective outward radiation. Certain considerations (see introduction) lead to the understanding that during the summer the melting part of the ice sheet was probably largely covered in clouds or fog (also because of the strong heat consumption), so that a considerable part of the required energy had to be generated by advective processes - heat introduced from the warm air brought to the glacier and rain falls. But since the global radiation budget provides many times these amounts of energy, this is easily possible. Even the extreme value of the eustatic increase of $50 \mathrm{~mm} / \mathrm{a}$ given by Fairbridge (1961a), corresponding to a melting of about $80 \mathrm{~cm} / \mathrm{a}$ of ice, still seems justifiable from an energetic point of view. Since the melting is concentrated in a few summer months, the summer runoff in the area average becomes very large; in addition, the concentration of runoff in the marginal areas leads to the formation of giant streams. To give an example: if we assume a lower Elbe a catchment area during the end of the glacial maximum of only about $2 \times 10^{6} \mathrm{~km}^{2}$, and a mean summer (5 months: May-September) precipitation of about $250 \mathrm{~mm}$, evaporation $225 \mathrm{~mm}$ and an ice melt $=125 \mathrm{~mm}$, i.e., a runoff component of about $1 \mathrm{~L} / \mathrm{m}^{2} \mathrm{~d}$, then this yields a runoff of about $23000 \mathrm{~m}^{3} / \mathrm{s}$, i.e., about $60 \%$ of the runoff today known from the lower reaches of the Congo or $20 \%$ of that of the Amazon river (Keller, 1961). Of course, this can be reduced by subglacial runoff into the Baltic Sea area.

Review statement. This paper was edited by Christine Thiel.

\section{References}

Abd El-Hady, S. S.: Vortrag WMO-ICAO-Seminar Cairo, Dez. 1961.

Balout, L.: Pluviaux interglaciaires et prehistoire sahariennie, Institut de Recherches Sahariennes, 8, 9-22, 1952.

Brooks, C. E. P.: Climate through the Ages, 2nd edn., Ernest Benn Limited, London, 395 pp., 1949.

Büdel, J.: Die Gliederung der Würmkaltzeit, Mitteilungen der Geographischen Gesellschaft Würzburg, 8, 45 pp., 1960.

Büdel, J.: Die pliozänen und quartären Pluvialzeiten der Sahara, E\&G Quaternary Sci. J., 14, 161-187, https://doi.org/10.3285/eg.14.1.18, 1963.

Butzer, K. W.: Quaternary Stratigraphy and Climate in the Near East, Bonner Geographische Abhandlungen, 24, Ferdinand Dümmler, Bonn, 157 pp., 1958.

Emiliani, C.: Cenozoic Climate Changes as indicated by the Stratigraphy and Chronology of Deep-Sea Cores of Globigerina-Ooze Fazies, Ann. NY Acad. Sci., 95, 521-536, https://doi.org/10.1111/j.1749-6632.1961.tb50057.x, 1961.

Fairbridge, R. W.: Eustatic Changes in Sea Level, Phys. Chem. Earth, 4, 99-185, https://doi.org/10.1016/0079-1946(61)900040, 1961a.

Fairbridge, R. W.: Convergence of Evidence on Climatic Changes and Ice Ages, Ann. NY Acad. Sci., 95, 542-579, https://doi.org/10.1111/j.1749-6632.1961.tb50059.x, 1961b.

Flohn, H.: Atmosphärische Zirkulation und Paläoklimatologie, Geol. Rundsch., 40, 153-178, https://doi.org/10.1007/BF01803224, 1952. 
Flohn, H.: Probleme der geophysikalisch-vergleichenden Klimatologie seit Alexander von Humboldt, Berichte des Deutschen Wetterdienstes, 59, 9-31, 1959a.

Flohn, H.: Kontinental-Verschiebungen, Polwanderungen und Vorzeitklimate im Lichte paläomagnetischer Meßergebnisse, Naturwissenschaftliche Rundschau, 12, 375-384, 1959b.

Graul, H.: Der Verlauf des glazialeustatischen Meeresspiegelanstieges, berechnet an Hand von $\mathrm{C}^{14}$-Datierungen, Deutscher Geographentag in Berlin 1959, Tagungsbericht und wissenschaftlichen Abhandlungen, 232-242, 1960.

Hoinkes, H.: Die Antarktis und die geophysikalische Erforschung der Erde, Naturwissenschaften, 48, 354-374, https://doi.org/10.1007/BF00623937, 1961.

Keller, R.: Gewässer und Wasserhaushalt des Festlandes, Haude \& Spenersche Verlagsbuchhandlung, Berlin, 520 pp., 1961.

Koch, H. G.: Meteorologische Studien im Mittelmeer, Band 1 der Abhandlungen des Meteorologischen Dienstes der Deutschen Demokratischen Republik, Akademie-Verlag, Berlin, 66 pp., 1950.

Lamb, H. H.: On the nature of certain climatic epochs which differed from the modern (1900-39) normal, in: Changes of Climate, proceedings of the UNESCO-WMO Symposium (Arid Zone Research XX), Rome, 1961, 125-150, 1963.
Lamb, H. H. and Johnson, A. J.: Climatic Variations and Observed Changes in the General Circulation, Geogr. Ann., 41, 94-134, 1959.

Schwarzbach, M.: Das Alter der Wüste Sahara, Neues Jahrb. Geol. , 4, 157-174, 1953.

Willett, H. C.: The General Circulation at the last (Würm) Glacial Maximum, Geogr. Ann., 32, 179-187, https://doi.org/10.1080/20014422.1950.11880829, 1950.

Willett, H. C. and Sanders, F.: Descriptive Meteorology, 2nd edn., Academic Press, London, 376 pp. https://doi.org/10.1002/qj.49708536520, 1959.

Woldstedt, P.: Das Eiszeitalter: Grundlinien einer Geologie des Quartärs, 3rd edn., volume 2, Ferdinand Enke, Stuttgart, 438 pp., 1961.

Zeuner, F. E.: Dating the Past. An Introduction to Geochronology, 4th edn., Methuen \& Co. Ltd., London, 474 pp., 1950. 